from TURTLE ISLAND to GAZA 


\section{MINGLING VOICES}

Series editor: Manijeh Mannani

Give us wholeness, for we are broken.

But who are we asking, and why do we ask?

-Phyllis Webb

Mingling Voices invites the work of writers who challenge boundaries, both literary and cultural. The series issues a reminder that literature is not obligated to behave in particular ways; rather, it can defy convention and comfort and demand that readers summon the courage to explore. At the same time, literary words are not ordinary words, and the series implicitly raises the question of how literature can be delineated and delimited. While Mingling Voices welcomes original work-poems, short stories, and, on occasion, novels-written in English, it also acknowledges the craft of translators, who build bridges across the borders of language. Similarly, the series is interested in cultural crossings, whether through immigration or travel or through the interweaving of literary traditions themselves.

\section{Series Titles}

Poems for a Small Park

Sefer

E.D. Blodgett

Ewa Lipska, translated by Barbara

Dreamwork

Bogoczek and Tony Howard

Jonathan Locke Hart

Spark of Light: Short Stories by

Windfall Apples: Tanka and Kyoka

Richard Stevenson

Women Writers of Odisha

Edited by Valerie Henitiuk and

Supriya Kar

Zeus and the Giant Iced Tea

Leopold McGinnis

Kaj Smo, Ko Smo /

Praha

E.D. Blodgett

What We Are When We Are

Cvetka Lipuš, Translation by

Tom Priestly

The Metabolism of Desire:

The Poetry of Guido Cavalcanti

Translated by David R. Slavitt

From Turtle Island to Gaza

David Groulx

kiyâm

Naomi McIlwraith 
from
TURTLE
to
I SLAND GAZA

David Groulx

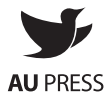


(C) 2019 David Groulx

Published by AU Press, Athabasca University

1200, 10011 - 109 Street, Edmonton, AB T5J 3S8

ISBN 978-1-77199-261-9 (pbk) ISBN 978-1-77199-262-6 (pdf)

ISBN 978-1-77199-263-3 (epub) doi:10.15215/aupress/9781771992619.01

Some of this work has appeared in Grey Borders and Rabbit: A Journal for Nonfiction Poetry.

Cover design by Natalie Olsen, kisscutdesign.com

Interior design by Sergiy Kozakov

Printed and bound in Canada

Library and Archives Canada Cataloguing in Publication

Groulx, David, 1969-, author.

From Turtle Island to Gaza / David Groulx.

(Mingling voices)

Poems.

Issued in print and electronic formats.

Canadiana (print) 20190064765 | Canadiana (ebook) 20190064781

LCC PS8563.R76 F76 2019 DDC C811/.54-dc23

We acknowledge the financial support of the Government of Canada through the Canada Book Fund (CBF) for our publishing activities and the assistance provided by the Government of Alberta through the Alberta Media Fund.

\section{Canadä'}



This publication is licensed under a Creative Commons licence, AttributionNoncommercial-No Derivative Works 4.o International: see www. creativecommons.org. The text may be reproduced for non-commercial purposes, provided that credit is given to the original author. To obtain permission for uses beyond those outlined in the Creative Commons licence, please contact AU Press, Athabasca University, at aupress@athabascau.ca. 
खा" 



\section{Preface}

I began writing From Turtle Island to Gaza in 2016, but the idea came to me several years earlier at a poetry reading in Toronto's Harbourfront, where I was reading from A Difficult Beauty. In the poem "Widening the Highway on the Rez" are the lines, "now this land becomes our Palestine / broken off from torso and limb / this long execution." After the reading, an older Palestinian man joined me for a smoke outside, and he told me how much he loved these lines. We spoke very little, as we both knew we shared that long execution - that distance, religion, education could not break what we shared. Colonialism is a shared experience. I've always known that, and I've always known that the Indigenous peoples here on Turtle Island were not the first or the only peoples to endure this long execution. I wanted to make what we have experienced here available to the world, believing that sharing stories is a power more powerful than bombs, bullets, or religion.

Some of the pieces address Palestinian poets-Mourid Barghouti, Mahmoud Darwish, Suheir Hammad, Rashid Hussein, Salma Jayyusi, Samih al-Qasim, Anton Shammas, Fadwa Tuqan, and Ibrahim Tuqan - I list their names here so you may hear them too.

In these poems I hope we find that we, colonized peoples, are not alone. 

1.0

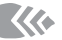

My

wing high

breaking distance

my voice

the sorrow

on the land

of a people.

A blood mercy. 
Beneath the snow

I sing a new note

taste a winter

coming

on my Circean tongue

Red River

wheels

escape.

I rekindle. 
The days of October

my wings will lyric and sway

for six days

I am crossing

a green line 

2.0

I am wearing

a blue line

across the desert sky

I braid the light

across the desert earth 
My loom

has become

black dust.

My wreaths

become

blood. 
I know not

to cry

while the rockets

bluster

and the snow

gruff and deep.

This fine white garment

clothes the earth. 

3.0

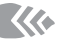

We are like the

wholeness of the sun

the light sinks

into the

earth.

Ritual

Remains. 
We are the road

allowance nation

it is our Ghazze

here we live

our songs

live. 
Sing now

to what is broken

lift your kisses

bring mercy

and raise us

from our

slumber. 
The spring is always

clouded

with snow

ah, the dust

of an angry

bolt

faithful

to bring

weeping. 
Sing me Fanon

Sing me inferno

Your

oscine shiver

over the catatonic

sleep of

Île-à-la-Crosse

and the Cedars

of Lebanon 



\section{0 ख}

Fly over the

broken peace

wave your bloody

wings

call the seditious

the intifada

serve our portion

of Azrael's sickle. 
The monster's skin

a pall of shit

Its bloating corpse

choking on

Apician graces 
I was Majdal

now I am Ashkelon

the ground

cursed by God

is settled

becomes unsettled. 
The earth becomes twisted

beneath the wheel

the wheel

scars

the earth.

What was

Red River

crumbles

beneath. 


\section{0}

The snow has fallen

and fallen

over Mount Tabor

over Ansar thee

now we are off the land

and held in acres of misery 


\section{1}

Winter crumbles

with what's left

grinds into the earth

A new corpse of spring. 
This place was called

'Ayn Hawd

now it is Ein Hod

the settlers

live there now

painting pictures

writing stories

our lives are

silent. 
Who will carry on the war?

that we made

that we live

Who will carry on the war?

when we go

into the bowels of our

enemy.

Who will finish

the slaughter? 
Dance with me once more show me where the worm the vulture and the maggot feast

Scatter my flowers that were gathered by this wretched beast Milkweed grows over my garden earth and butterflies pass into the earth. 

6.0

I've been invited

to leave my country

as you have yours

Shammas

perhaps we could

leave

together

We sacred kings 
Find a new country

to bury our dead

leave the land

of your pilgrimage

I leave the land

to the white settlers 
6.2

Where should we go?

You and I

Where can we go?

We, Refuge

refuge refuse

from the occupied 
6.3

We become aliens

strangers

outsiders

foreigners

unknown

in our own land

other 
6.4

Samih

this soil is sacred

like water

My land is holy

too

and

from it

I cannot be severed 
It is Canada day here Samih

everyone is happy

because it's a holiday

I do not know

what to feel 
The land becomes pale and the birds

do not recognize

it

the birds

sing

the land is

silent

barren

with no reply 
Rashid

there is a Settler's daughter

in a headdress

a star of David

in her mouth

her hands wrapped

in barbed wire 
Dear Mahmoud

Here I am

without our lives

we live in prisons

of poverty

behind walls of despair

but fortunately Mahmoud

we do not live long. 


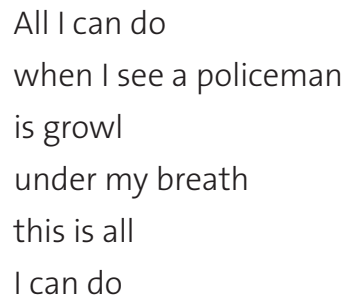


When we speak of freedom

we must also speak of our freedom

to be kind

to be just

and to be in love

when we speak of freedom

this is what we

must speak of 
The Lakota call white people Wasi'chu meaning steals the fat. The Anishinaabeg call white people Zhaaganaash meaning fell from the sky. White people call us Indians because they think they are in India. 
8.0

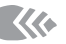

The language I speak

are the walls of my prison

the language I speak are

the bars of my prison

The words I speak

are a history of the

death of language. 
If we know our oppressor

lives in prisons of anger

How can the settler

be our master? 
Israel has built a wall around itself a narrow prison.

Past the wall

the earth swallows

lentils

and boiled eggs 
Mahmoud

Men will use anything to take our land

Guns, bombs, swords.

The word of God, but mostly

the twisted word

of God. 
The earth has been untied from me untied from my barbarian heart untied from my black ash hair. My bone has become untied from my skin. My mouth untied from my tongue. Now only the earth grows in my ear. 
Today Mahmoud

I worked all day in the freezing rain shoveling snow

from foundations.

The day was cold,

but I can think of

others

that made me old. 
The history books say

you left Al-Tira

willingly.

Mortars and machine guns

can do this.

A bullet has a way of

convincing like no other.

We know my friend

that bullets and bombs

cannot kill

the dirt that runs

through our veins. 
I live under this iron

where there are two goats

one is black, one is white

One is given to the lord

The other to the valley

I follow the one

that is lost 
We are stuck in the throat of a settler.

Like a chicken bone from a hen whose throat has been slit and yet bleeds in the barnyard. 

9.0

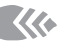

A Windigo is not a djinn

My dear friend

A Windigo was once a man

with an unquenchable appetite.

That he craved the flesh of Indians.

but you and I know

it is our land. 
Is suicide as common there as it is here? Mahmoud.

I knew a young Indian boy once, he found his oldest sister hanging in his closet dead.

After her funeral his younger sister hung herself also. The boy doused himself in gasoline and lit himself on fire and the ice was thin enough he fell through No the young boy was not a phoenix. He did not rise up out of the ashes. Those are only stories.

This one I could touch.

He was only a young Native boy. I cry Mahmoud, when I remember it.

Is suicide as normal there as it is here, Mahmoud? 
I am closer to Rome than you are I see its flickering lights at night I hear the fighter jets ringing toward you see the tanks rolling toward you the warships lifting anchor do not go to Damascus do not go to Beirut do not go to God it is not safe there. You are closer to Rome than I am 
The siege came to us and forced us off the land.

The siege then taught us English and left us speechless.

The siege showed us its riches and left us in poverty.

The siege dragged us to its school and left us wretched.

The siege taught us its work and left us unemployed.

The siege taught us its war and left us murdered.

Buried us in heaps and forgets about us. 
The missing are prisoners of our memory.

Our leaders bray like donkeys to the settler. I write poems no one reads, and the settler feeds them more carrots. 
That woman of Rome

We carry her on our shoulders, you and I.

It is our business, our

bread and butter.

Her wounded border, where

daylight escapes and night time

enters, our bellies

drag us along. 
This soil

in my palms

was the place of God

howling

to the four directions

This soil

is his flesh

He cannot abandon it. 
And Samson said, "Let me die with the Philistines." Judges 16:30 (KJV)

Call out to God

That I may leave

my thunder and lightning on this earth

peace be upon him.

That I may

lay the broken jawbone

and broken pillars

here in the grace

of Canaan. 
Mourid you said it was fine to die on a clean white pillow

You said it was fine to die of old age is this what I am afraid of?

I dream I am drowning in the rivers of the country

That someone is holding me there Here is a clean white pillow beneath the currents 
Hold me Fadwa

because we know

memory knows no compromise

The blood does not negotiate

The songs of our ancestors will not make us

or our oppressor comfortable 
Salma

If Palestine was the size of Canada

they would have put you on reservations far

off in the bush

away

so they didn't have to look at you

didn't have to see any of your number

didn't have to see the suicide of your children

After all they are only brown

after all

Let you die there dirt poor

without any clean water to drink or bathe in and then say don't look at those dirty Palestinians

They are poor and dirty

in the land god gave to us

and the land god gave to you

they say god gave to them

as if god is only books and bullets 
Our lives are unpalatable to them and then they claim they had nothing to do with it

It was God

Suheir

It was always God 
Name your oppressors Ibrahim

create a space with your words and whisper it to me

and we can share it and

in this space

together create hope.

The sound of the name

creates hope.

Hope that begins

breaking at the first word

like dawn. 
a 